\title{
The Curtain Between the Images
}

\section{Robert Bramkamp}

The artist Susanne Weirich recently exhibited a poetic machine which promises to prophecy or to herald good fortune: The FortuneTelling Machine (1995). ${ }^{1}$ In my film Prüfstand 7 [Test Stand 7], ${ }^{2}$ a creature appears that similarly wishes to herald something. There is, however, a problem. A curtain surrounding planet earth prevents this creature from meeting us and from speaking or heralding events in its own appropriate language. Unlike the curtain in Weirich's The Word Wolke (2001), another work which seems to be in dialogue with rocketry, this curtain is impenetrable, and the sphere behind it remains invisible. ${ }^{3}$ But sometimes the curtain turns into a surface for projection. Then we see various styles of images: we see pictorial discourse of, on and about the rocket projected onto it. The first five minutes of Prüfstand 7 give an impression of how these different picture dialects are connected within the film-and of the way Bianca (the name of the creature) wanders through them. ${ }^{4}$

\section{First extract from Prüfstand 7 (running time 0:00:00 to 0:04:45 $[\text { hr:min:sec] }]^{5}$}

Bianca: I was the first to fly into space, and my image came to life.

I have experienced things I would like to reveal, but there is no way for us to meet. Your planet is shrouded by a curtain I can't get through.

Whenever my desire to meet you becomes strong enough, then you can see me and I can see you. But I'm not really there.

I live between the pictures you create of your own world.

I am trying to find out where I come from.

He: I can help you.

Bianca: Who are you?

A map will be lying in the car. I am in Peenemünde, Germany.

It says here, "the cradle of space travel" - Test Stand 7-dear rocket lovers, and I'll show you my favorite failed take-off.

Seven cameras for one $\mathrm{V}-2$ ! Not even an actress gets that much attention! Hello? Hello? 
Speaker 1: Peenemünde.

Bianca: Hello? My map says: Nordhausen, Germany.

Andreas: The world's largest underground factory was built under Mt. Kohnstein, near Nordhausen, in the Harz Mountains. The workers came from Mittelbau-Dora, a concentration camp located next to the factory. The production of over 6,000 rockets cost the lives of 20,000 prisoners. $^{6}$

The piles of ashes around the crematorium were still smoldering when the American Army arrived on April 11, 1945. . . The dead were already invisible.

All the rockets, documents and rocket parts were taken away by the Americans.

He: I'll show you the "oven." That is what the Germans called the rocket's combustion chamber. The oven carried you into space.

Bianca: I know nothing about the oven.

It looks organic. It's just lying around on the beach. . . .

He: . . . In Peenemünde. They are testing the combustion chamber for the V-2 rockets. They don't realize that they are preparing your birth.

Bianca: Do I come from the oven?

Bianca's search follows a trail through the myth of the rocket. We encounter fascination-at the outset German fascination-with this first, so concrete object of autonomous technology, of a technology which has begun to lead a life of its own. The character study of a machine emerges. This machine brings together everything we are no longer able to bring together. As we know from Gravity's Rainbow, "the Rocket has to be many things, it must answer to a number of different shapes in the dreams of those who touch it" (727). So it has to be at once super phallus, machine bride, young girl, old witch, technology with 20,000 individual pieces, spirit, ghost, inspiration and finally vampire.

Hence, in the context of "art as science" and/or "science as art," the rocket, on the one hand, figures as the product of exact sciences such as physics, chemistry, aerodynamics, mathematics and information technology, and at the same time, on closer examination, on the other hand, radiates a shimmering ambiguity. "'There's a poetry to it,'" Pynchon writes, "'engineer's poetry'" (207). So are we dealing with a product of the sciences which is art? Or does the rocket, by means of engineer's poetry, trigger effects which are similar to art but 
which compete with it? Effects which have, in fact, overtaken art? In this respect, is it science instead of art?

Bianca's search links the origins, the present and the projected future of the rocket. This is helpful since the processes are often clearer in the case of the original technical object: while we have become accustomed to the "Lift off! We have a lift off!" at the launch of rockets, it was still clear with the original object that we were not lifting off, but that something new was separating itself from us, and that at best it was taking something of us with it. Rather than "lift off," the final words "Stecker gefallen" - "Stecker 1 und 2 gefallen,' Moritz reports. The Stotz plugs lie blasted on the ground" (758)-mean "connection broken." An umbilical cord was cut, irrevocably. Presumably, another connection was broken, or severed, along with it: the one between classical art practice, guided by poetic function, and a new, different practice we might call fascination art or technology art.

Bianca follows the crew of the German filmmaker Völckers to England, where a strange scenario pays tribute to the quasi-artistic status of the rocket.

Second extract from Prüfstand 7 (running time 0:23:05 to 0:24:15)

Bianca: With a new sound man, filmmaker Völckers continues his research in England.

In Antwerp he had heard that the British were restoring an original V-2 rocket-as if it were a Rembrandt.

Weinstein: Yes. Well, the first thing is that the rocket is reconstructed only by women.

These are women who have previously worked on reconstructing sixteenthand seventeenth-century paintings.

And they have a kind of painstaking alertness to the "beingness" of the rocket, which one would normally go into repairing a Rembrandt.

Bianca: In search of a V-2 and twenty art restorers, he travels to Birmingham.

Sheila: It's the first restoration of a military rocket.

I think I can safely say, I'm the first woman ever to take a V-2 apart.

A "painstaking alertness to the 'beingness' of the rocket"? Bianca's legend of the curtain behind which she is invisible - where perhaps the rocket's dead are invisible too, making the area behind the curtain into a kind of beyond-was found in England to have an unexpected technical analogue. An invisible separation device, a division within the 
oven, permitted the rocket to take off, to say adieu to our world and adieu to the art necessary in it. When Pynchon alludes to this curtain in Gravity's Rainbo w - "'a film of alcohol on the inside of the chamber'" with which one "'can reduce the heat transfer by a considerable amount' " he indicates that the division between two spheres, brought about by the curtain, could have more influence in our lives than we think: "In this quarter-hour at Peenemünde, Pökler smiled more than he had in the year previous: spoke of his admiration for Poehlmann's work in devising a cooling system for the propulsion. 'What about the hot spots?' Weissmann asked. It was a reasonable question, but also an intimacy" (416).

Third extract from Prüfstand 7 (running time 0:24:50 to $0: 26: 35$ )

Bianca: Curtain cooling ${ }^{8}$

Tech-Frau: The "curtain" consists of alcohol that flows through the oxygen tank. Together with the oxygen, it reaches a temperature of 3,200 degrees centigrade. The steel oven would melt, if it weren't for the curtain of alcohol.

Bianca: What kind of curtain is it?

Sheila: What they did is: the alcohol is taken in here, and is taken all the way down.

And this in fact is double skinned. It's double walled, and the alcohol goes inside and keeps it cool.

Bianca: I see. The alcohol flows through a double wall, and then?

Sheila: And at the same time, a very very small amount of it - there's little tiny holes inside-goes inside the combustion chambers and up the walls.

So you have a skin film of cold alcohol, and this is stopping the metal from burning. $^{9}$

John: You have a nice cool film. I don't know how many millimeters.

Sheila: And it's being used to isolate the combustion chamber from the burning fuel.

Bianca: How cold? How cold is this curtain?

Sheila: John knows temperatures. I don't want to give you the wrong temperatures. 
Bianca: Are there two curtains?

... Or is it the same one?

One may ask whether the curtain is identical with the new boundary area or interface which Pynchon sees as the secret target of the rocket system: "an interface between one order of things and another" (302). Which two orders are these? During my work on the film, I occasionally followed Laurence Rickels, who differentiates between the fast track of technology and the slow track of language, imagination, love. The fast track of technology champions the direct and the simultaneous, and its output is fascinating - "fascinating" much in the sense of Avital Ronell, who maintains that fascination blinds. The fast track promises eternity, and, as Rickels asserts, every science fiction film is searching for a point of entry where man and the machine are able to meld into one. Actual research into a "temporarily eternal non-mortality" is taking place in the United States and elsewhere. Conspicuously, the most modern space research of the Deutsche Gesellschaft für Luft- und Raumfahrt (DLR) stages similar phantasms, using, for example, a system called Bremer Hose. ${ }^{10}$

The slow track, which we also inhabit, the sphere of language, imagination, love - of mortal bodies, one might add-is unable to offer simultaneity and, in that sense, timelessness. We need spans of time, and we also need to be able to account for an end to these. The slow track - the sphere in which the poetic function is able to intervenedepends on a symbolic environment: the seven days of the week, the four elements, yin and yang, twelve apostles and twelve testing bases in Peenemünde. But according to Friedrich Kittler, Europe and its technology left precisely this symbolic realm of complete numbers when it began to base its knowledge, via differential calculus, on the unlimited numbers behind the point-on the sphere of real, physical processes which can be dealt with reliably only if one uses computers as number crunchers (Kittler 119).

Whatever it is that the curtain divides, one can with historic precision name the date when this division, split or separation happened for the first time: October 3, 1942. On the outside of the rocket, one could still discover a piece of classical art: a futile and naïve attempt at camouflage, it showed a picture prophesying good luck, ${ }^{11}$ based on Fritz Lang's film Die Frau im Mond (1929).

In my film, I reproduce the sounds of amplified noises and voices from this first successful launch of a large modern rocket, and link them with a voice-over of the reminiscences of Walter Dornberger, the military director of the Heeresversuchsanstalt Peenemünde. All quotations are word-for-word Dornberger's. 
Fourth extract from Prüfstand 7 (running time 0:26:36 to 0:30:12)

Tech-Frau: October 3, 1942. Test version 4 is prepared for takeoff. Another faulty launch, and that would be the end.

He: General Dornberger remembers:

Domberger: I was happy to be alone with my friend Colonel Zanssen. The minutes seemed like hours.

The rocket's slender black and white body appeared on the screen with all its dazzling beauty.

Would we finally witness a successful launch today? The reward for ten years of painstaking efforts?

After three seconds, the rocket switched over to its own systems.

I saw the cables fall.

Speaker: $\quad 1,2,3,4,5,6,7,8,9,10,11,12,13,14,15,16,17 \ldots$

Dornberger: Now . . . The rocket didn't fall apart. That was one weight off my mind.

The rising pitch indicated that the rocket was still accelerating.

All I could see was its vapor trail and a tiny red dot blinking at the tip. My heart was pounding madly. I confess, I was speechless.

My colleagues later honored me by placing a stone with a nice inscription in Peenemünde's forest to symbolize the weight that had fallen from my mind.

Bianca: I was conceived without a mother.

I am the child of the rocket. But where do I come from?

He: We opened the gates to the universe, and you were brought to life.

Bianca: Who is we?

He: What did you experience?

Bianca: Who are you?

Tech-Frau: The successful launch of the A4 rocket - later called V-2-marked a technological achievement with enormous repercussions. London and Antwerp were defenseless against 3,600 rockets.

The A4 also paved the way for today's space travel and to the twenty-first century's International Space Station. 
Words failed; a silent stone was symbolically placed-and someone once said, "The old stones are pure pain." Pain-without which we seldom learn and seldom produce art-is banished to the woods, put aside. But language is also losing its influence. At the end of the sequence, you probably noticed the ambivalence of the rocket as a death-bringing weapon of destruction on the one hand, and the explorer of new worlds on the other, discovering outer space as humankind's future dwelling-place. This ambivalence is radical. And it reminds one of the "Manichaeans who see two Rockets, good and evil, who speak together in the sacred idiolalia of the Primal Twins [. . .] of a good Rocket to take us to the stars, an evil Rocket for the World's suicide, the two perpetually in struggle" (GR 727). Indeed the good and the bad sides of the rocket, and all the other contradictory sides of its character have for about sixty years been connected by a simple "but it is also . .." It was possible to postpone the struggle perpetually. The radical ambivalence of the rocket finds expression in its regular fluctuation between military and civilian employment; it is symbolically inscribed in the DLR's life-saving Bremer Hose, which operates on the boundary of death; and it is displayed in the way the Rocket shimmers between a dead machine and an animated idol.

Every critical discussion of the rocket underlines and amplifies its ambivalence, and, what is more, enforces this radical ambivalence as a victorious attitude. Or, to put it differently: the rocket offers a performance which is decisive to people who do not want to decide. The rocket is an utterly clear, conclusive jein, ${ }^{12}$ putting an end to all the talk and to our doubts. Only then does it bring the talk to the point, the point of impact.

In the rocket's jein lies a fundamental farewell to language or dialogue. For technologically dreamed immortality can do without, can dispose of language. Kittler points to the psychic conditions of this immortality with his formula "calculate rather than think," adding that this means "I leave the language in which I have grown up" (121). There is no longer any necessity for the mirror either - this property a person requires in order to recognize his own face as that of a human. Technological immortality cannot be illustrated. Does its zone lie behind or within the curtain?

Together with space medic Friedhelm Baisch, the inventor of the Bremer Hose, Bianca makes an experiment. The Bremer Hose is not only a machine that assures the survival of astronauts aboard the International Space Station; it also has a potentially lethal effect, and, quite by the way, it rehearses the combination or melding of man and machine. ${ }^{13}$ 
Fifth extract from Prüfstand 7 (running time 1:37:55 to 1:39:22)

Baisch: Essentially, you'll never lose the concept of the umbilical cord with all these things. The moment you are forced to employ such a system, you link up. And if you accept the metaphor, you can say that all the things we have developed here stem from the idea of creating an extended umbilical cord: a kind of information channel for astronauts, monitoring them in their environment.

Bianca A: Is there a passageway? Or a gateway?

Bianca B: Or not a passageway, but a wall, a screen?

Baisch: I would say, you can even immerse yourself in a picture. I don't believe that technological evolution ends in front of a wall.

Bianca B: I am there.

Bianca A: Where are you?

Bianca B: Where you aim to go...

Bianca B: ... but no voice exists here ...

$I$ am in the land where there is no ego . . . inside the curtain.

Should our position today already be within the curtain (in case we have been keeping up a complicated division between two forms of existence for a long time ${ }^{14}$ ), rocket technology warns us that the curtain between the two forms-our efforts to remain radically ambivalentuses up the greatest part of existing energy. By contrast, art as science would assert a genuine ambiguity, bound to poetic function. A possible strategy to win back some terrain is to turn the metaphorical side of science into artistic material and thus a) take everything into account (even if it does not initially appear attractive in terms of filmmaking), and b) separate what is mixed and link what is separated in a new, exciting way.

The aim here would be a pragmatic attitude tying in with a feelingshall we say, "desire for connectivity" versus "technical fascination"? It remains open if and how this strategy can reciprocally influence the direction of those questions posed by the exact sciences.

- Hochschule für Film und Fernsehen 
Notes

'Weirich's installation Die Glücksprophezeiungsmaschine [The FortuneTelling Machine] was exhibited for the first time at the Landesamt für Denkmalpflege München, December 2001-January 2002. For current information, see www.susanneweirich.com.

${ }^{2}$ The film premiered in German theaters in June 2002, and was broadcast by 3SAT in Switzerland, Austria and Germany in November 2002. For further information, see www.pruefstand7.de. The DVD release, including an English version, is scheduled for 2004 by Edition Salzgeber: see www.salzgeber.de.

${ }^{3}$ Weirich and I gave a joint lecture on the imagery of curtains at the interdisciplinary symposium "Art as Science-Science as Art": see www.kunstals-wissenschaft.de. The present text is based on a transcription of my part of that lecture.

${ }^{4}$ The name Bianca and the character obviously have nothing in common with the Bianca in Gravity's Rainbow. Rather, the Bianca in the film is intertwined in various ways with the novel: as a reader of the novel (she comes to read it, cursorily, at the KZ Dora Memorial); as a figure living between the filmlike narrated pictures of Gravity's Rainbow as, similarly, between the pictures of our world; and as a proclaimer of her own cause and existence as opposed to those she derives from the novel: "There was an alternative to the rocket, a lovable spirit, Bianca. But Slothrop had to follow the rocket, and Bianca had to leave." This remark of hers indicates that she must have listened to Vaska Tumir at the 1998 Pynchon conference in Antwerp: "In the course of his peregrinations in the Zone, [Slothrop] commits his one act of betrayal for which there is no pardon. On board the Anubis (named after the Egyptian god who conducted the urban dead), Slothrop abandons Bianca to her eventual death" (Tumir 147).

${ }^{5}$ The film was made mostly without a shooting script. The extracts are translated transcriptions of voice-over and dialogue. For running times, counting begins with the first frame of the film.

${ }^{6}$ For the report of a former Dora inmate, see Elzenga.

${ }^{7}$ The German Stecker gefallen may be rendered literally as "connector fallen"-connection broken.

${ }^{8}$ Literally, Schleierküh/ung means "veil cooling," not "curtain cooling"; however, the British report on Operation Backfire translated it as "curtain cooling." In the German version of the film, Bianca usually speaks of a veil (Schleier), a half-transparent curtain.

${ }^{9}$ See Thorsten Heß, historian at the Dora Memorial, for details of the production process (Heß 83).

10 "Bremer Hose" means "Bremen Trousers." It is a system (technically, LBNP) that puts the lower body under negative pressure. It serves aboard the 
International Space Station as a medical-training tool for a kind of space bodybuilding, a workout device necessary to prepare for the return to earth.

${ }^{11}$ Test version 1-50 showed individual "good luck pictures": see Krüger 67.

${ }^{12}$ The German jein, made from ja ("yes") and nein ("no").

${ }^{13}$ See Baisch for a discussion of the implications of online medical monitoring (via LBNP and ATEM) of astronauts in near-death situations, and of his version of the curtain/veil.

${ }^{14}$ For a discussion of the curtain/veil as "most secret interface," see Kittler 125-26.

\section{Works Cited}

Baisch, Friedhelm. "Interview mit Friedhelm Baisch." Interview by the author. Bramkamp and Fedianina 136-40.

Bramkamp, Robert and Olga Fedianina, eds. Prüfstand 7: Das Buch zum Film. Material zum Film und Andere Forschungen zum Geist der Rakete. Berlin: Maas, 2002.

Dornberger, Walter. V-2. Trans. James Cleugh and Geoffrey Halliday. New York: Viking, 1954.

Elzenga, Godfried. “Die Mißlungene Englandfahrt: Erlebnisbericht des Niederländischen Dora-Häftlings Godfried Elzenga, Häftlingsnummer 22976, Geboren am 01.08.1921." Bramkamp and Fedianina 85-95.

Heß, Thorsten. "Interview mit Thorsten Heß." Interview by the author. Bramkamp and Fedianina 78-84.

Kittler, Friedrich. "Interview mit Friedrich Kittler." Interview by the author. Bramkamp and Fedianina 113-28.

Krüger, Reinhold. "Interview mit Reinhold Krüger." Interview by the author. Bramkamp and Fedianina 65-74.

Prüfstand 7. Dir. Robert Bramkamp. Next Film, 2001.

Pynchon, Thomas. Gravity's Rainbow. 1973. London: Picador, 1975.

Rickels, Laurence A. The Case of California. Baltimore: Johns Hopkins UP, 1991.

Ronell, Avital. The Telephone Book: Technology-Schizophrenia-Electric Speech. Lincoln: U of Nebraska P, 1989.

Tumir, Vaska. "The City, the Labyrinth and the Terror Beyond: Delineating a Site of the Possible in Gravity's Rainbow." Pynchon Notes 42-43 (1998): 134-51.

Weirich, Susanne. Die Glücksprophezeiungsmaschine. Berlin: Goldrausch Frauennetzwerk Berlin, 1995.

---. The Word Wolke. Oldenburg: Edith-Russ-Haus für Medienkunst, 2001. 